\title{
Augmentation of Saline Streams by Concentrated Solar Distiller with Mini Solar Pond
}

\author{
M.Gowtham, M.Sharath Chander
}

\begin{abstract}
An attempt was made to enhance productivity of concentrated parabolic solar distiller by integrated it with convective type mini solar pond. Basin was segmented into number of trays for higher contact area. Experiments conducted to improve productivity by increasing various factors like Heat storage capacity, exposure area, maintaining low depth. In a mini solar pond, experiments were conducted for different salinity. It was found that the optimum value of salinity in the mini solar pond is $80 \mathrm{~g} / \mathrm{kg}$ of water. Exposure area is improved by using sponges and heat transfer rate is improved by using scrap metals. Productivity of water was measured every hour between 9 A.M to 5 P.M by maintaining lower depth. Overall productivity was improved by $49 \%$ by using various modifications.
\end{abstract}

Index Terms - Desalination, Mini solar pond, Solar, Parabolic trough concentrator.

\section{INTRODUCTION}

Lack of fresh water is one of the most important problems that whole world faces these days. Along with the supply of energy, access to freshwater is a fundamental need of all societies. There are various methods for desalination for production of pure water. Solar desalination is the energy conserving technology now being adopted in most of the gulf countries. Energy storage plays important roles in conserving available energy and improving its utilization. Short term storage of only a few hours is essential in most applications such as improving the latent heat storage, sensible heat storage plays a vital role in conservation of energy. Solar ponds are used for collection and storage of solar energy. Thereby the energy can be extracted for any suitable thermal application. Working of a solar pond is very simple. Salts like magnesium chloride, sodium chloride or sodium nitrate are dissolved in the water with the concentration varying from $20 \%$ to $30 \%$ at the bottom to almost zero at the top.M.M. El-Kassaby[2] studied the complete design and fabrication for a distilled water apparatus using a line concentrator of parabolic reflector type, which can be used for sea water distillation along with a steady state theoretical model based on energy balance is presented. Mehmet (2000) also evaluated the thermal performance of a cylindrical storage tank linked to a solar powered heat pump used for space heating with a heat pump. M.F. El-Refaie [3] has made analytical study of the performance of the stationary

Manuscript received June 7, 2011

Gowtham M et al., Department of Mechanical Engineering, Thiagarajar College of Engineering, Madurai, Tamilnadu, India.

E-mail: gowthamtce@gmail.com reflector/tracking-absorber (SRTA) solar collector with tubular absorber and found different multi-reflection zones of the mirror. Oommen and Jayaraman [4] analysed non-evacuated CPC cavities with flat or cylindrical absorbers. Rene tchinda [5] presented a mathematical model for computing the thermal performance of an air heater with a truncated compound parabolic concentrator having a flat one-sided absorber. Naghelli Ortega et al. [6] studied effect of concentrator as vapour generator for solar-ammonia and water adsorption refrigerator. S.Sentilkumar[7] found the effectiveness of three dimensional parabolic concentrator over two dimensional trough which is utilized for stream generation in in-situ stream generation mode. Rabl A [8-10] compared parabolic concentrator and studied the effect of maximum concentration. Balasubramaniam $\mathrm{V}$ et al. [11] designed a concentrator with stretched membranes. Phadatare MK [12] proposed that basin water depth is having significant effect on productivity of the solar still. Investigations show that, the water depth is inversely proportional to the productivity of still. Sanjeev Kumar et al. [13] suggested that, for maximum annual yield, the optimum collector inclination for a flat plate collector is 20 degrees and that of still glass cover is for New Delhi climatic condition. Rajesh Tripathi and Tiwari [14] inferred that the convective heat transfer coefficient between water and inner condensing cover depends significantly on the water depth of the basin. It is also observed that more productivity was obtained during the off shine hours as compared to day time for higher water depths in solar still $(0.10$ and $0.15 \mathrm{~m})$ due to storage effect. Vimal Dimri et al. [15] conducted theoretical and experimental analysis of a solar still integrated with flat plate collector with various condensing cover materials. The results indicated that yield is directly related to thermal conductivity of condensing cover materials; copper gives a greater yield compared to glass and plastic due to higher thermal conductivity. Tiwari et al. [16] inferred that, the internal heat transfer coefficients should be determined by using inner glass cover temperature for thermal modeling of passive and active solar stills. Kiatsiriroat [17] analyzed the performance of a multiple-effect vertical active solar still integrated with a flat plate solar collector. Zaki [18] experimentally investigated an active solar desalination system of a conventional single slope solar still integrated with a flat plate collector which operated in the thermosyphon mode. Kaygusuz [19] also carried out an theoretical and experimental study to determine the performance of PCM storage, and the variation of the outlet temperature with different values of NTU (the number of transfer units of the storage unit) for water-based solar heating systems. Tiwari et al. [20] presented an analysis of 
PCM storage for a water heater by incorporating the effect of water flow through a parallel plate placed at the solid-liquid interface. Wick type solar stills [21], a plastic water purifier [22] and stepped solar still were developed. The materials that improves the heat transfer were studied by velmurugan et al[23]. The effect of various depth of water [24] in the solar still is verified by Khalifa and Hamood. Velmurugan et al. integrated a mini solar pond with single basin solar still for enhancing the productivity of the still from salt water. The productivity was increased by $57.8 \%$ when solar pond was integrated with the single basin solar still. . Hildbrand et al. Tahat et al. produced a portable mini solar pond and analyzed the performance. Also they determined the effect of depth in various zones of solar pond and its water's salinity on store's temperature distribution both by experimentally and theoretically. The parabolic concentrator solar distiller with latent heat storage material integrated with mini solar pond is studied. To enhance the productivity the solar distiller, materials like sponges, pebbles, mild steel billets are used.

\section{EXPERIMENTAL SETUP}

In this Experimental setup, a solar concentrated distiller and mini solar pond is connected in series. Basin of solar distiller is divided into trays for higher contact area. Solar ponds are used for collection and storage of solar energy. Construction of solar pond is provided with three zones. Fresh water is added at the top of the pond, while slightly saline water is run off, at the same time, concentrated brine is added at the bottom of the pond. Three zones, namely upper convective zone (UCZ), non-convective zone (NCZ) and lower convective zone (LCZ) are being maintained in the solar pond. Salinity in UCZ is very less and close to fresh water. In NCZ, salinity increases with the depth. As there is no natural convection in this zone, it is called as NCZ. The solar radiation transmits this zone and increases the temperature uniformly with the depth. LCZ is dense and has a uniform and high density of salt (close to saturated brine). This zone is acting as a storage zone. Maintenance of depth of the gradient zone is essential for the efficient use of solar ponds. The inner surfaces of the pond were painted with black color to increase rate of the solar radiation absorption. To preheat the saline water in the mini solar pond, a swirled copper tube was used. Heat can be extracted from solar pond through two modes namely, batch mode and continuous mode. In this work, water is not sent through the mini solar pond continuously. For every half an hour, the hot water is taken from the mini solar pond and send to solar still. The same quantity of the water will supply to the solar pond. So, in this work batch mode of heat extraction was used. The solar pond was fabricated as truncated conical shape. The diameter at the top layer was $300 \mathrm{~mm}$ and the diameter at the bottom layer was $100 \mathrm{~mm}$. The upper convective zone was at a height of $80 \mathrm{~mm}$ from the top surface. The total height of the pond is $300 \mathrm{~m}$. Prasad et al. estimated the thickness of lower convective layer of solar pond. Using the estimation, it was taken as $100 \mathrm{~m}$. The intermediate zone or the non-convective zone was $120 \mathrm{~mm}$ from the top. The copper tube of $7 \mathrm{~mm}$ diameter was swirled as a coil structure in order to have more contact area with the hot salty water. The inlet of the copper coil was connected to the collecting tank, which was placed beneath the settling tank. The outlet of the mini solar pond is connected to the basin type still and tray type solar still. The flow rate of effluent through the copper coil was being regulated by means of the valve V1. Solar distiller integrated with mini solar pond shown in fig 1 . Values v1 and v2 are used to control the flow of saline water from tank to the mini solar pond and from solar pond to the basin of the concentrator respectively. Basin of length $0.9 \mathrm{~m}$ and diameter $0.15 \mathrm{~m}$ is provided for evaporating the saline water. It is fabricated of $2 \mathrm{~mm}$ thick GI sheet and coated with black paint to increase the absorption of heat. Parabolic concentrator of length $1 \mathrm{~m}$ and width $0.5 \mathrm{~m}$ depth $0.125 \mathrm{~m}$ is used to concentrate solar thermal energy to the basin made out glass mirror. These dimensions were calculated based on which concentration of sunlight focuses on the basin. Concentrator is tilted to various angles manually every hour. Basin is covered with double slope glass cover for condensing the distilled water. Trays are provided on the basin, which increases the exposure area of the system. Glass cover is inclined in 10 degree on both sides. Leather sheet was used to prevent leakage from any gap between the glass covers and the still box Poly Vinyl Chloride (PVC) tubes were used to discharge the distilled water from each unit to the bottles. The inlet water was fed into the still using flexible hoses. Various modifications done are explained.

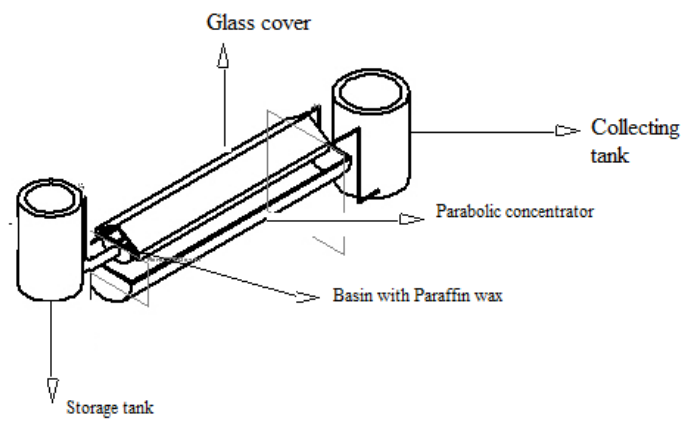

Fig 1. Experimental set-up

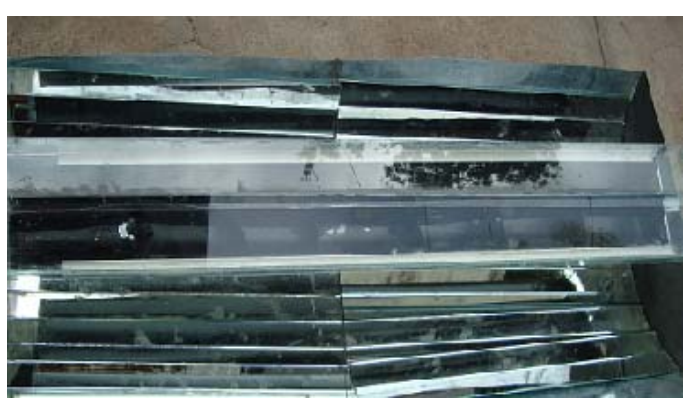

Fig 2. Solar distiller

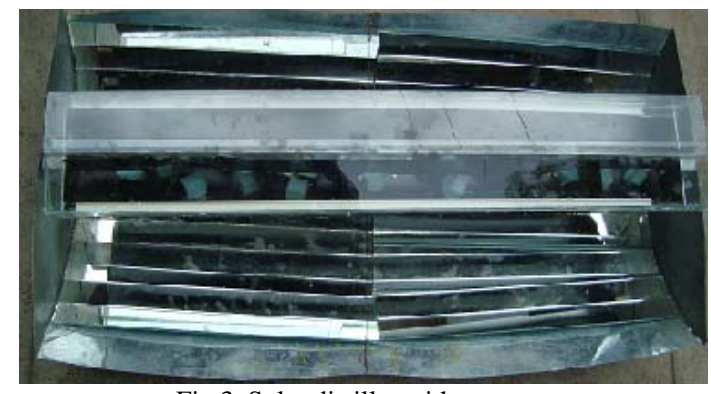

Fig 3. Solar distiller with sponges 


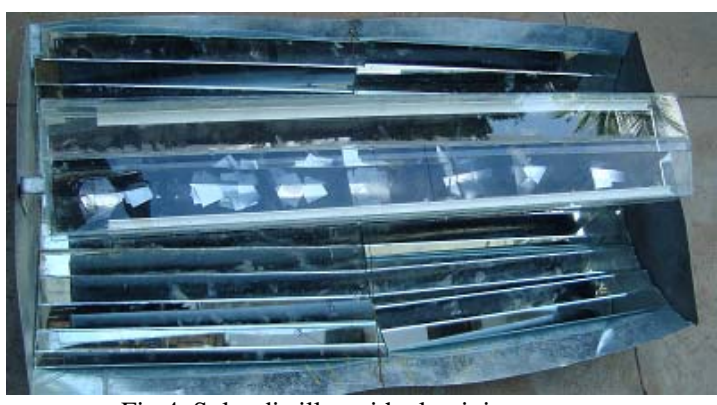

Fig 4. Solar distiller with aluminium scraps

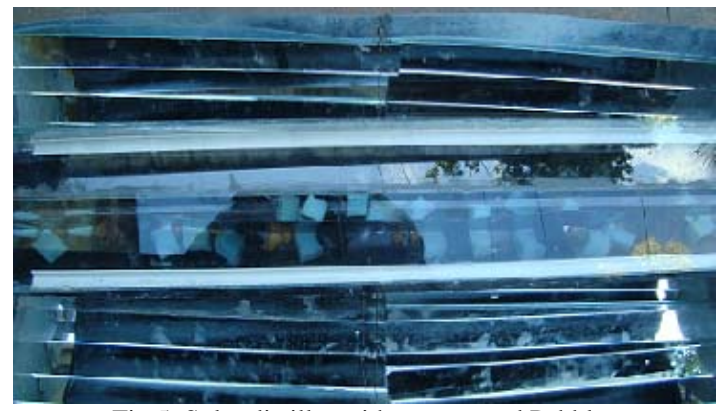

Fig 5. Solar distiller with sponge and Pebbles

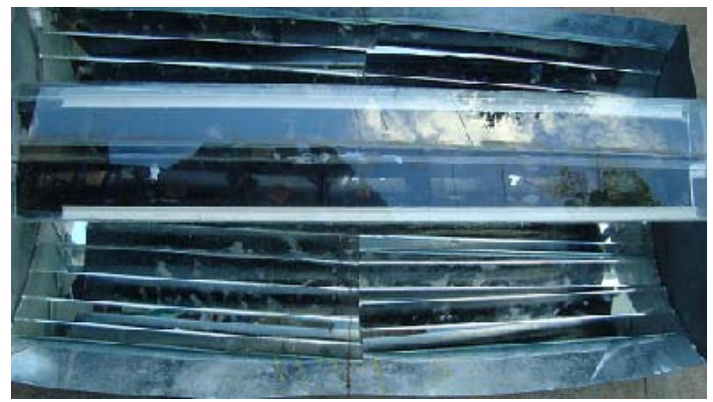

Fig 6. Solar distiller with Steel billets.

\section{A. Solar distiller with trays:}

The concentrated parabolic solar distiller integrated with mini solar pond is studied. The evaporation rate is improved by the contact area of the basin shown in figure 2 .

\section{B. Solar distiller with Aluminium scraps:}

In the solar distiller with trays, Aluminium scraps having high thermal conductivity are added as in figure 4, leads to heat storage capacity of the basin is improved

\section{Solar distiller with Sponges:}

To increase water exposure area, sponges were used in solar distiller as in figure 3 . The exposure area increases due to the capillary action. This will increase the evaporative area as well as evaporation rate.

\section{Solar distiller with sponges and Pebbles:}

Pebbles were added to previous modification shown in figure 5. It was observed that the productivity of still increased due to the higher volumetric heat capacity of the pebbles.

\section{E. Solar distiller with Mild Steel billets:}

In the solar distiller with trays, Mild steel billets having high thermal conductivity are added as in figure 6 , leads to heat storage capacity of the basin is improved.

\section{RESUlTS AND DisCUSSION}

Concentrated solar distiller with trays, sponges, pebble, Aluminium scraps and mild steel billets were used to enhance the productivities of the solar distiller along with mini solar pond. Performances of the solar desalination unit with various modifications were studied. Productivity of the system for depth of $1 \mathrm{~cm}$ and $2 \mathrm{~cm}$ depth are measured.

\section{A. Solar distiller with trays and mini solar pond:}

The graphs drawn below illustrates the variation of productivity with time for various depths in which the basin containing trays. The water output increased in lower depth for each hour due high heat transfer. The productivity was about $30.56 \%$.

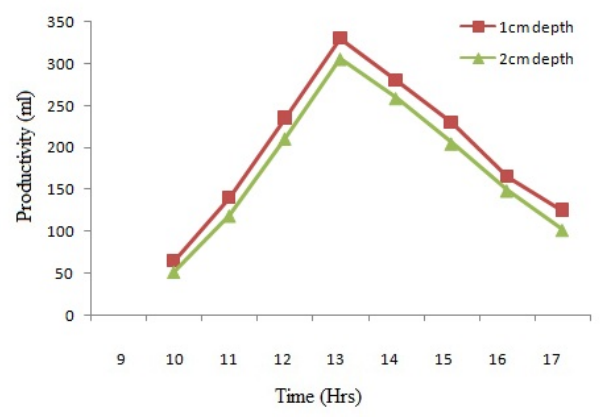

Fig 7. Productivity of distiller with tray

\section{B. Solar distiller with Aluminium scraps:}

It is observed that solar distiller with aluminum scrap has increased productivity to $49 \%$ in tray type solar distiller with mini solar pond compared to conventional type.

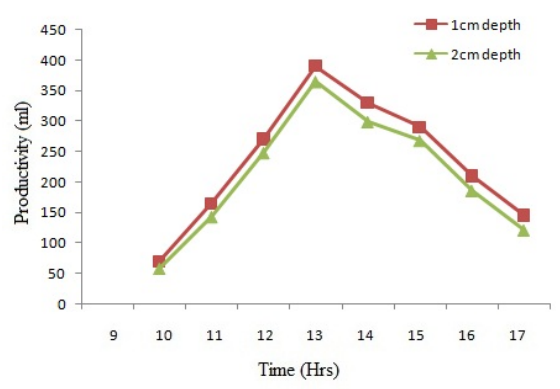

Fig 8. Productivity of distiller with Aluminium scraps

\section{Solar distiller with Sponges:}

It is observed that due to the presence of sponges, the water output is increased to $34.41 \%$ in tray type still due to the addition of sponge when compared to conventional still.

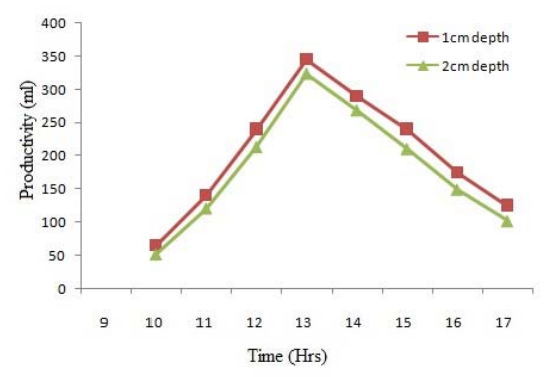

Fig 9. Productivity of distiller with sponges 


\section{Solar distiller with Pebbles:}

Due to the presence of sponges and pebbles, the overall water output is increased to $39.85 \%$ when compared to conventional still Because Volumetric heat storage of pebbles.shown in fig. 10 .

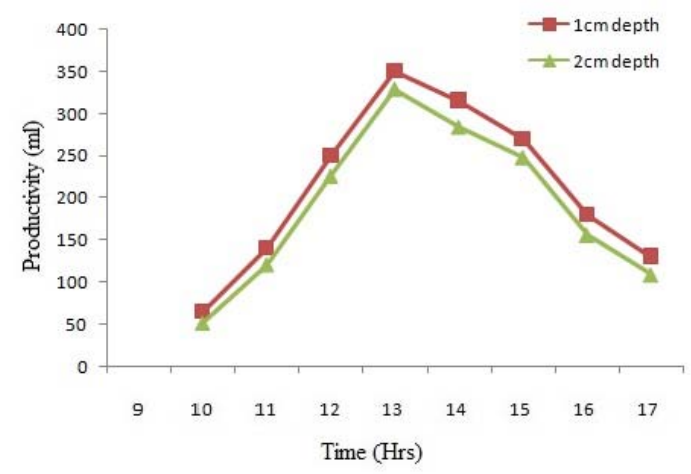

Fig 10. Productivity of distiller with sponges and pebbles

\section{E. Solar distiller with Mild steel scraps:}

Due to presence of mild steel scraps heat storage capacity and thermal conductivity of metal increases the productivity to the maximum of $44.08 \%$ compared to the convention setup.

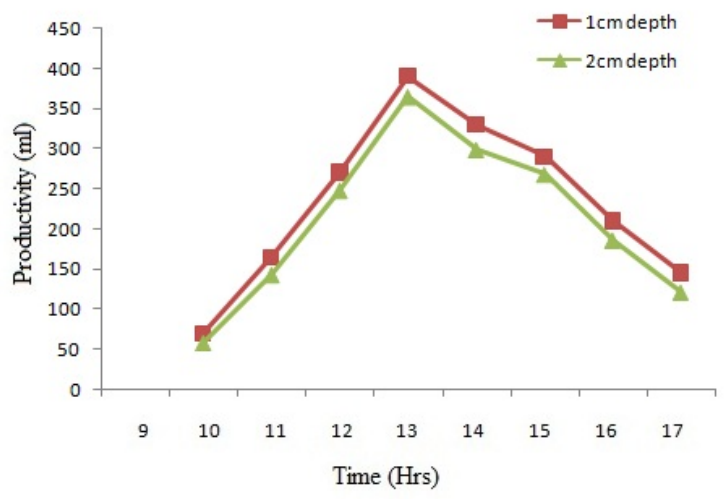

Fig 11. Productivity of distiller with Metal billets

\section{F. Productivity of solar distiller:}

The following graphs shown below was the comparative illustration of the productivity of various modifications using sponge, pebbles and mild steel scraps per day. The bar chart shown below fig. 12 was per day productivity of solar distiller for different materials.

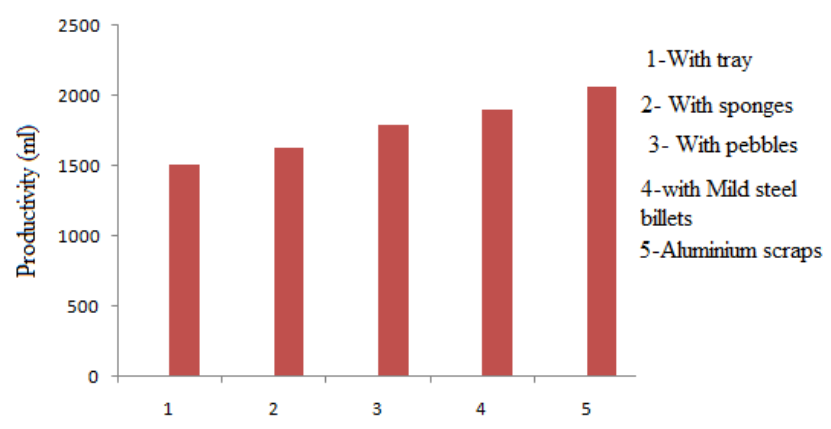

Fig 12. Overall Productivity of solar distiller

\section{CONCLUSION}

Experiments carried out with solar distiller individually analyzed having $49 \%$ higher productivity compared to conventional solar distiller. Analysis on maintaining lower depths were studied. Overall productivity based on the various materials was studied.

\section{REFERENCES}

[1] http://www.ceemeng.mit.edu/Stevens.pdf.

[2] M.M. El-Kassaby, Parabolic type solar still, Renewable Energy, volume 1, 1991, pages 449-454.

[3] M.F.El-Refaie, Performance analysis of the stationary -reflector / tracking-absorber solar collector , Energy Conversion and Management Volume 29, Issue 2, 1989, Pages 111-127.

[4] R. Oommen ,Development and performance analysis of compound parabolic solar concentrators with reduced gap losses - oversized reflector, Energy Conversion and Management Volume 42, Issue 11, July 2001, Pages 1379-1399

[5] Réné Tchinda, Thermal behaviour of solar air heater with compound parabolic concentrator , Energy Conversion and Management, Volume 49, Issue 4, April 2008, Pages 529-540

[6] Naghelli Ortega, Roberto Best, Adrián Oskam, and Octavio García-Valladares, World Renewable Energy Congress VIII (WREC 2004), Copyright 2004, Published by Elsevier Ltd.

[7] S.Senthil kumar, K.Perumal, P.S.S.Srinivasan, Optical and thermal performance of a three-dimensional compound parabolic concentrator for spherical absorbers, Sahana, part 4 vol.34, june 2009, pp 369-380.

[8] Rabl A, Goodman N B \& Winston R, Practicl design considerations for CPC solar concentrators, solar energy,issue 22 373-381

[9] Rabl A, Solar concentrators with maximal concentration for cylindrical absorbers, Applied Optics, issue 15 1871-1873

[10] Rabl A, Comparison of solar concentrators, solar energy, issue 18 93-111 C. J. Kaufman, Rocky Mountain Research Lab., Boulder, CO, private communication, May 1995.

[11] Balasubramanian V \& Sankarasubramanian G, The stretched membrane design of a compound parabolic trough collector, renewable energy for rural development, proc NSEC published by Tata Mc-Graw Hill publishing Co ltd,New Delhi 1989,77-81 M. Young, The Techincal Writers Handbook. Mill Valley, CA: University Science, 1989.

[12] Phadatare MK, Verma SK. Influence of water depth on internal heat and mass transfer in a plastic solar still. Desalination 2007;217-267

[13] Kumar Sanjeev, Tiwari GN, Singh HN. Annual performance of an active solar distillation system. Desalination 2000;127:79-88.

[14] Tiwari GN, Shukla SK, Singh IP. Computer modelling of passive/active solarstills by using inner glass temperature. Desalination 2003;154:171-85.

[15] Dimri Vimal, Sarkar Bikash, Singh Usha, Tiwari GN. Effect of condensing cover material on yield of an active solar still: an experimental validation. Desalination 2008;227:178-89.

[16] Tripathi Rajesh, Tiwari GN. Effect of water depth on internal heat and mass transfer for active solar distillation. Desalination 2005;173:187-200.

[17] T. Kiatsiriroat, P. Wibulswas and S.C. Bhattacharya, Performnace analysis of multiple effect vertical solar still with flat plate collector, Solar Wind Technol., 4(4) (1987) 451-457.

[18] G.M. Zaki, A. Al-Turki and M. Al-Fatani, Experimental investigation on concentrator assisted solar stills, Solar Energy, 11 (1992) 193-199

[19] Kaygusuz, K. (1995b). Experimental and theoretical investigations of latent heat storage for water based solar heating system. Energy Conversion and Management 36(5): 315-323.

[20] Tiwari, G.N., Rai, S.N., Santram, Singh M. (1988). Performance prediction of PCCM collectioncum- storage water heater: quasi-steady state solution. Energy Conversion and Management 28 (3): 219-223.

[21] Ward John. A plastic solar water purifier with high output. Solar Energy 2003;75:433-7.

[22] Minasian AN, Al-Karaghouli AA. An improved solar still: the wick-basin type. Energy Conversion and Management 1995;36:213-7.

[23] Velmurugan V, Senthil Kumaran S, Niranjan Prabhu V, Srithar K. Productiv- ity enhancement of stepped solar still-performance analysis. Thermal Science 2008;12:153-63.

[24] Abdul Jabbar N Khalifa, Ahmad M Hamood. On the verification of the effect of water depth on the performance of basin type solar still. Solar Energy 2009;83:1312-21. 